\title{
The Lost Trail of Dewey
}

Eco's Problematic Debt to Pragmatism

Robert E. Innis

\section{(2) OpenEdition \\ Journals}

Electronic version

URL: http://journals.openedition.org/ejpap/1159

DOI: 10.4000/ejpap.1159

ISSN: 2036-4091

Publisher

Associazione Pragma

\section{Electronic reference}

Robert E. Innis, «The Lost Trail of Dewey », European Journal of Pragmatism and American Philosophy [Online], X-1 | 2018, Online since 20 July 2018, connection on 19 April 2019. URL : http://

journals.openedition.org/ejpap/1159; DOI : 10.4000/ejpap.1159

This text was automatically generated on 19 April 2019

\section{(c) $($ ) $(9)$}

Author retains copyright and grants the European Journal of Pragmatism and American Philosophy right of first publication with the work simultaneously licensed under a Creative Commons AttributionNonCommercial-NoDerivatives 4.0 International License. 


\title{
The Lost Trail of Dewey
}

\author{
Eco's Problematic Debt to Pragmatism
}

Robert E. Innis

\section{A Problematic Debt}

1 Umberto Eco's philosophical project, which culminates in the development of a systematic and philosophically relevant semiotics, has a perplexing and problematic debt to and link with pragmatism in its many forms. Indeed, his apparent relation to pragmatism as such is in fact quite tangential if we ignore the pivotal role of Peirce in defining and supporting Eco's explicit semiotic turn. Eco's appropriation of Peirce was highly selective. It focused predominantly, as one would expect, on central foreground features of Peirce's theory of signs: the schemas of sign functions, the nature of interpretants, problems surrounding iconism, and, perhaps most importantly, the heuristic fertility of Peirce's notion of semiotic openness or infinite semiosis for a theory of the interpretation of texts, primarily linguistic but also in an extended sense with respect to aesthetic 'texts' in general.

2 Peirce's metaphysical categories play a negligible role in Eco's world view, which was expressed already in his early works, The Aesthetics of Thomas Aquinas (1988) [hereafter: ATA] and The Open Work (1989) [hereafter: OW]. In these two books much is made of the emergent picture of a decentered cosmos, permeated by forces of cosmic drift that marked the putative radical break with the classical and medieval and even early modern world view. Eco saw the work of James Joyce as a prime linguistic-aesthetic exemplification of the nature and scope of the bewildering effects as well as implications of this turn in our world picture - or at least of our Western world picture rooted in classical Greek philosophy and the type of aesthetics systematized by Aquinas, even if not completely exemplified in other Medieval reflections on art and beauty of a broader phenomenological scope, which Eco examined in his Art and Beauty in the Middle Ages, with which I will not be concerned in this essay.

3 However, looked at as a philosopher, Eco did not utilize the analytical tools or engage the full range of concerns of the whole pragmatist tradition to develop a distinctively 
'pragmatist' semiotics or even a 'pragmatist' aesthetics or 'pragmatist' account of experience. The themes of the Jamesian philosophical project of a radical empiricism, with its wide range of concerns extending, developing, and modifying the philosophical thrust of his great Principles of Psychology and mirroring in existential and experiential detail Peirce's 'vitally important questions,' and the descriptive thickness of Mead's attempt to develop a nuanced pragmatist social psychology, which is clearly linked with a social semiotics and the social matrices of the formation of the semiotic self, play no meaningful role in Eco's work.

4 Nevertheless some strong links to John Dewey's Art as Experience (1934) [hereafter: AE] in Eco's first two books provoke reflection and can help us situate Eco's relation to pragmatism. But Dewey plays no important thematic or explicit role in Eco's work thereafter. Such an absence raises a question about a 'path not taken' or a 'lost trail' in Eco's philosophical wanderings and on any attempt to link him, as a philosopher, with pragmatism as a whole, which is not by any means identical with, or represented by, Peirce. Such a situation is all the more perplexing in light of Eco's remark in his autobiography about the essential formative and liberatory role of Dewey's Art as Experience in freeing him from the Idealistic premises and tendencies of the Italian philosophical and aesthetic thought of his student days, exemplified in various degrees in the work of his teacher, Luigi Pareyson.

5 Paradoxically, there are substantive links of a phenomenological order between Pareyson and Dewey, once one gets past their different metaphysical premises with their religious implications. Eco's 'secular' turn is paralleled by Dewey's naturalistic turn, but Dewey turned it into a kind of existential empowerment without the hint of a perhaps not unjustified nostalgia that lingered in Eco. Dewey's picture of the universe was of a "moving unbalanced balance of things" (Dewey 1925: 341). In such a world, Dewey writes in Human Nature and Conduct, we are in need of objects and symbols that grasp and hold our consciousness, giving us a sense of "encompassing continuities with their infinite reach" and of the "enduring and comprehending whole" (Dewey 1922: 226). But, practicing a kind of pragmatist hermeneutics of suspicion, Dewey warns against attachment to symbols "which no longer serve, especially since men have been idolators worshiping symbols as things," even if in these symbols there is still "some trace of a vital and enduring reality" (1922: 226). It is sentiments such as these, a sentiment of 'cosmicity' informed by a religious naturalism that Eco saw latent in certain sides of Dewey's Art as Experience although he distanced himself from it on the philosophical and existential plane.

6 Art as Experience appears to be the only major work of Dewey that Eco read, or at least cited, although there are allusions in Kant and the Platypus (1999) [hereafter: KP] to Dewey's connection with a 'transactional' theory in the psychology of perception and to the Peircean background to his 'detranscendentalized' notion of 'warranted assertion.' The lack of any serious engagement with Dewey outside of the contexts of Eco's first two books is a pity. In certain important respects Dewey's pragmatism, which itself was not developed without adverting to Peirce, can extend, enrich, and even recontextualize both Eco's 'presemiotic' early work and his predominantly Peircean later investigations of perception, language, meaning, art, and social forms, themes that were the focal points of Dewey's own life long reflections.

7 Clearly, I cannot fully engage all these topics in the course of one essay. Instead, I will trace the links, both historical and systematic, connecting Dewey's experience-based 
pragmatist aesthetics with Eco's ultimate framing of the task of aesthetics in semiotic terms. Eco himself in A Theory of Semiotics (1978) [hereafter: TS] wrote that one of the tasks of semiotics was to deal with "the genesis of perceptual signification" at the lower thresholds of experience "where referents are no longer confronted as explicit messages but as extremely ambiguous texts akin to aesthetic ones" (TS 167). Dewey formulated his fundamental principle in the following way: "The thing most fundamental to esthetic experience [is] that it is perceptual." (AE 222). When Dewey claimed that it is "to esthetic experience [...] the philosopher must go to understand what experience is" (AE 278), the aim was not just to understand it, but to be challenged by it. What a work of art does, Dewey argues, is to "concentrate and enlarge an immediate experience [...] the meanings imaginatively summoned, assembled, and integrated are embodied in material existence that here and now interacts with the self. The work of art is thus a challenge to the performance of a like act of evocation and organization, through imagination, on the part of the one who experiences it." (AE 277).

Perception, signification, and interpretation are inextricably linked. This is the Deweyan thread whose wandering lines in Eco I will trace in the following discussion.

\section{Deweyan Threads in The Aesthetics of Thomas Aquinas}

9 In The Aesthetics of Thomas Aquinas, in the chapter, "The Formal Criteria of Beauty," discussing the notion of proportion or consonantia in Aquinas, Eco writes:

[...] proportion is based upon the vital reality of form [...]. It does not signify something static and crystallized in a motionless perfection, but rather a dynamic unity. It is a dynamic unity because it involves a combining of living forces which do not annul or rigidify themselves when they combine; rather, they confer life upon a type of activity whose value derives from their several vigorous and operative energies. The result is one of unity in variety, a unity which does not constrict the multiplicity of movement but merely regulates it and directs it to its end. (ATA 95)

10 A reader may be shocked by what follows in what could be considered a kind of Urtext of Eco's intellectual career since it comes from a philosophical tradition so different from that in which this still readable and admirable book on Aquinas arises. It is a long passage from John Dewey's Art as Experience. Here is the text cited by Eco.

There is an old formula for beauty in nature and art: Unity in variety. Everything depends upon how the proposition "in" is understood. There may be many articles in a box, many figures in a single painting, many coins in one pocket, and many documents in a safe. The unity is extraneous and the many are unrelated. The significant point is that unity and manyness are always this sort or approximate it when the unity of the object or scene is morphological and static. The formula has meaning only when its terms are understood to concern a relation of energies. There is no fullness, no many parts, without distinctive differentiations. But they have esthetic quality, as in the richness of a musical phrase, only when distinctions depend upon reciprocal resistances. There is unity only when the resistances create a suspense that is resolved through cooperative interaction of the opposed energies. The "one" of the formula is the realization through interacting parts of their respective energies. The "many" is the manifestation of the defined individualization due to the opposed forces that finally sustain a balance. (AE 166) 
11 Eco then comments on the preceding passage by offering a Deweyan gloss on or affirmation of one of Aquinas's core insights. But such an interpretation contravenes one of his objections to Neo-scholastic attempts to see things in Aquinas that are not there or to use them for their own (misguided) purposes. Eco's book is in fact not just an historical reconstruction but in a way just as much a selective validation of aesthetic concepts in Aquinas which, as it turned out, bordered on Dewey's framework. Eco writes:

It seems to me that formal proportion, as defined by Aquinas, has precisely these dynamic characteristics, just because it is proportion in an organism which exists, which lives. There is a dynamic tension which causes matter and form to combine in the individual, and a dynamic tension which transports essence into the excitement of existence. If we leave the plane of metaphysics, we still find a dynamic tension among the parts of things, and between subject and object in cognition. All proportion is dynamic, because it is the coefficient of perfection, the coefficient of existence. (ATA 96)

12 There are no other references to Dewey in this book. But there are echoes of central Deweyan themes throughout Eco's reconstruction of Aquinas's aesthetics: form, relation of energies, distinctive differentiations within the art work, the creation of suspense, the notion of esthetic quality, reciprocal resistances, cooperative interaction of opposed energies, defined individualization, balance, and so forth. Other Deweyan notions appear in a different format, but not linked explicitly to him. One familiar with Dewey's Art as Experience has a lingering uneasiness about the neutrality of Eco's historical reconstruction of Aquinas's aesthetics.

13 For example, in the discussion of Aquinas's opusculum, De Mixtione Elementorum, Eco thinks that its import transcends the context in which Aquinas developed his thoughts about bodies composed of other bodies or elements. In such bodies, Eco writes, paraphrasing Aquinas, the qualities of the simpler bodies are "turned toward and absorbed into a new quality which belongs properly to the new mixed body and is dependent on its form." Such qualities, as Eco puts it, "survive as a continual alignment of the active 'virtues' of the simple bodies" (ATA 96). The notion of 'active powers' or "dynamic energies, which subsist and remain active" in the 'mixed body,' is actually the source of its life, or what Susanne Langer called its 'livingness.' The pivotal notion is 'formal dynamism,' a fusion or integration of form and energy. This is the mark of every "organism that exists, whether natural or artistic, spiritual or sensible" (ATA 97). Such a remark is a mélange of different terminological frames. Eco's foregrounding of such a notion is perhaps not in itself an anachronism, but the use of the term 'organism' in an aesthetic context is likely influenced by his reading of Dewey. This is made even more likely by what follows. Speaking of proportion, looked at transcendentally, as having an infinity of analogues, Eco writes: "Every existent, beautiful in that it possesses existence, can present us with new and unsuspected types of proportion. The possible proportions are infinite in number, both in the world of nature and in art." (ATA 97). This is what Dewey is referring to in his remark that an art work is a "unique transcript of the energy of things of the world" (AE 189). Art, Dewey writes, "intercepts every shade of expressiveness found in objects and orders them in a new experience of life" (AE 110).

Later, in the chapter on the aesthetic visio and the 'peace' that marks it, Eco writes of a "balance of energies" inducing a peace that on the epistemological level means "the total delight of a contemplative perception which, freed from desire and effort, experiences love of the harmony which the intellectual judgment has shown to it" (ATA 200). As to balance of energies, Dewey writes that the "final measure of balance or symmetry is the 
capacity of the whole to hold together within itself the greatest variety and scope of opposed elements" (AE 184). The love of a harmony is love of a particular quality of experiencing, a quality that is a Peircean 'tone.' Eco, arguing against Maritain's neoScholastic reconstruction of Aquinas, denies that this experience is something that occurs prior to the labor of abstraction which would, according to Maritain, introduce an extraneous intellectual element into the aesthetic visio. According to Eco, seemingly following Aquinas but perhaps also indicating his own position at that time, "aesthetic pleasure is total and complete because it is connected with a cessation of the efforts of abstraction and judgment. It signifies, not an absence, but a cessation, of effort. It is a sense of joy and triumph, of pleasure in a form that has been discerned, admired, and loved with a disinterested love, the love which is possible for formal structure." (ATA 200; original emphasis). But it is puzzling that at this point Eco has recourse to Pareyson and not to Dewey, who in many contexts engaged this issue or the frameworks in which this issue is discussed.

Eco cites a fine passage from Pareyson at this point, although he could have cited any number of passages from Dewey. Here is the Pareyson passage:

Interpretation has two aspects. On the one hand, it is an active process intended to grasp the true meaning of things, to fix the meaning in an image that is penetrating and exhaustive, to give it a shape that is vigorous and adequate [...] This process tends toward a state of quietude in which it stops and rests; and this is, precisely, the second aspect of interpretation. For on the other hand, interpretation means quietude and stasis - the quiet discovery and success, the stasis of possession and satisfaction [...] The eye, which before this was sharpening its gaze, now just looks and admires, intent, satisfied. It rests with pleasure upon the whole and upon its parts, happy to have discovered the law of coherence which gathers everything into a definite totality. It is contented at having understood the heart and nerve center and the nature of the breath which animates the form which it has put to the question. (ATA 200, citing Estetica 161-2)

Eco draws a conclusion from this that the question of the aesthetic in Thomas Aquinas "seems to have a paradoxical form [...] in light of modern aesthetics" (ATA 200), although it is not clear which part of modern aesthetics he is referring to. Intellectual knowledge, he claims, is the generative matrix of Aquinas's conception of the distinctively aesthetic visio. Aquinas, Eco argues, takes beauty not to be the fruit of psychological empathy nor of the imaginative transfiguration of the object - as if this polarity exhausts the alternatives. Rather the roots of beauty for Aquinas are to be found deep in the knowledge of being. "And so, intellectual travail is a necessary pathway to the knowledge of beauty." (ATA 201). This comment foreshadows the intellectual turn in Eco's own framing of the discussion of aesthetics in A Theory of Semiotics, where the Deweyan focus on experiential processes passes unnoticed and unexploited in favor of 'high' theory.

17 Aesthetic visio, for Aquinas, is, Eco rightly says, "an act in which I apprehend a formal reality" (ATA 190). For Aquinas, Eco writes, formal reality is perceived precisely as a structure (ATA 190) with a splendor and clarity for us who engage it. For Aquinas beauty is "a state of equilibration between a perfect object and the intellect" (ATA 191, cited after M. Febre, "Metafisica de la belleza," Rivista de filosofia, 7, 1948, 91-134). Beauty is apprehended when we contemplate formal structure in an ecstatic and fruitful moment quieting other instrumental and existential urgencies. Eco here seemingly combines the expository and the argumentative, since this is one of Dewey's principal claims. Indeed, is there not perhaps an echo of Dewey's distinction between the art product and the art work 
in Eco statement that aesthetic visio is the "aesthetic actuation of an ontological perfection which was aesthetic only in potential" (ATA 191)?

What exactly is the aesthetic visio, clearly a theme posed by Eco on his own? It is neither sensation nor pure abstraction but rather "apprehension in which we grasp some principle of organization of the sensible. Beauty involves both form and a material together" (ATA 192). Indeed, while "aesthetic value is rooted in the concreteness of things" (ATA 193) Eco remarks that within the limits of Aquinas's philosophy there is no "intuition of form in the sensible. In fact the scope for movement within his philosophy is extremely limited" (ATA 194; original emphasis), even though Eco's first allusion to Dewey as a gloss on Aquinas seems to indicate something else. Eco is striving, in spite of himself, to show dynamic elements in Aquinas both on the level of interpretation and on the level of the constitution of the object that is apprehended aesthetically. And moreover, on Aquinas's principles, there is some indirect knowledge of the singular by reflection upon the phantasm (see pages 195-6 in ATA for Aquinas texts). Aquinas's thesis, as formulated by Eco, is that "aesthetic seeing does not occur before the act of abstraction, nor in the act, nor just after it. It occurs instead at the end of the second operation of the intellect - that is, in the judgment." (ATA 196; original emphasis).

The first operation of the intellect is the apprehension of a quidditas, an 'essence' or 'quiddity,' what a thing is to be. The grasp of properties, accidents, and relationships incidental to the thing's essence follow. The intellect, according to Aquinas, "accordingly [...] must necessarily either combine one apprehension with another or separate them" (ST I 85 54c). So, as Eco points out, we have as secondary originary acts of the intellect operations of joining and separating, the marking out of properties, accidents, and contexts and, on the Scholastic principles of Aquinas, as Eco puts it, "it is only in the act of judgment that I can determine whether a proportion measures up to my capacity to experience it and to my psychological needs, and whether it also conforms with (say) the laws of music and is adequate to what its nature demands" (ATA 198), hard as it is to think of Aquinas speaking of 'psychological needs.' But, in a remarkable comment, Eco writes that "every intellectual endeavor which culminates in judgment has, in some degree, an aesthetic outcome" (ATA 198), distinctive qualitative feel.

20 As a matter of fact we can find parallel passages in Dewey that make the same points. And clearly the effort of aesthetic abduction has the same type of outcome, as Peirce also pointed out. So, it is an interesting question of why Eco had subsidiary recourse to Pareyson as a supporting text on the matter of the aesthetic visio and not the deeply pragmatic approach exemplified in Dewey's Art as Experience.

21 How deep was his reading of Art as Experience at the time he was writing his Aquinas book? This question is not meant so much as a criticism as noting a lost opportunity to increase the sense of pragmatist linkages with materials that lay ready to hand and were from time to time alluded to.

Consider, as examples, the following Dewey texts in light of the putative double operation of the intellect in Aquinas and of Eco's criticism of Maritain and the scholastics as to the relationships between aesthetic visio and the nature of the links between abstraction, interpretation, perception, and the swing and sway between activity and passivity in the aesthetic encounter. Here is the first text:

We say with truth that a painting strikes us. There is an impact that precedes all definite recognition of what it is about. As the painter Delacroix said about this first and preanalytic phase, "before knowing what the picture represents you are seized 
by its magical accord." This effect is particularly conspicuous for most persons in music. The impression directly made by an harmonious ensemble in any art is often described as the musical quality of that art. (AE 150) references to Dewey's pragmatist aesthetics, although there are background resonances in his analyses. Of special note is his minimizing the role of claritas in Aquinas. This is strange in light of his claim about the importance of Dewey's perceptual orienting of aesthetics and of the emphasis on dynamic powers in Aquinas. To be sure, Eco intended the Aquinas book to be an intellectual reconstruction, to place Aquinas correctly and solidly in his time. At the same time his selective allusions to Dewey and to Pareyson seem to follow, albeit schematically, the same hermeneutic logic he was antipathetic toward in the neo-scholastic appropriations of Aquinas. Eco offers us a compact summary of the preceding discussion.

Let us take stock. The beauty of an object is identified, in Aquinas, with its perfection, its fullness of being. It is the coefficient of this perfection that the object be subject to the transcendental law of proportion, because of which it is an organism with a structure, and the structure corresponds to a particular order. In its purely formal aspect - the aspect which is of interest in aesthetics - a perfect object is an object which has integrity and proportion, and nothing more is required. Its form is complete, ontologically ready to be judged beautiful. To speak of the 'resplendence' of the form is simply a figure of speech for referring yet again to integrity and proportion, the wholeness of which saturates and coordinates the constituent parts. (ATA 119)

In fact, the saturating and coordinating factor is what Dewey called the unifying felt quality of a work of art resident in its perceptual supports, giving it its resplendence. When Eco remarks that "Scotist theory brings us to a new aesthetic world" (ATA 207) with its foregrounding of haecceitas, a notion that deeply influenced Hopkins and also Joyce, and is clearly operative in Aquinas, one wonders why, as in the earlier pages, there is such a hesitation to make further linkages. But it is clear that the Deweyan background, while present, is faint in Eco's first work.

\section{Poetic Language as Exemplar. Transaction and Expression}

Dewey appears more extensively and explicitly in The Open Work, first in the chapter, 'Analysis of Poetic Language,' in the opening section on Croce and Dewey, where Eco is speaking in his own voice. The opening theme is the inner logic or aim of a work of art "to be an inexhaustible source of experience" and to originate a continuous stream of new aspects as it is engaged. It generates, ideally, "a series of meanings that expand at every 
new look" (OW 25). Croce, Eco remarks, thought of artistic representations as reflections of the cosmos with a claim to a kind of totality such that it incorporates "the entire drama of reality" (cited on p. 25) - clearly not explicitly in detail but in potentia with a network of implications it gives rise to or can unfold without limit. This is the way, Eco says, to understand Croce's statement that "a true artistic representation is at the same time itself and the universe, the universe as individual form, and the individual form as universe" (cited on p. 25). The concentrated image embodies a feeling, Eco says, having a distinctive quality, a 'lyrical' quality in Croce's conception. But, Eco objects, Croce had no theoretical framework with adequate philosophical tools to explain its nature. We have a specific type of pleasure in undergoing the experience of the work of art but cannot explain the mechanism that realizes it.

Eco then pivots to Dewey, who expressly had distinguished himself from Croce's idealism. Eco frames the issue as the "conditions of aesthetic pleasure" (OW 25) and the way of explaining their mechanism. He foregrounds some well known central texts from Dewey's Art as Experience, although it is not clear that he is aware of their source in Dewey's work, namely in James's Principles of Psychology which constantly lurks in the background. Croce's sense of a totality, Eco claims, refers to, in Dewey's words (AE 198), "this sense of the including whole implicit in ordinary experiences," something also carried by a work of art which is a meaningful whole or theme embedded in a field and enveloped by an aura of resonances at the receding margin. Indeed, for Dewey, the focal and explicit objects of the foreground of experience are surrounded, or accompanied, as Dewey says (AE 198), by "a recession into the implicit which is not intellectually grasped. In reflection we call it dim and vague," qualities of an experience prior to what Eco calls, with hyperbole, the "categorical rigidity imposed on us by reflection" (OW 25). Eco cites Dewey to the effect that the essence of art lies in its power to evoke and emphasize "this quality of being a whole and of belonging to the larger, all-inclusive, whole which is the universe in which we live" and then, perhaps alluding to one of Dewey's own remarks, that there is a religious dimension inspired in us by aesthetic contemplation. But it is a religious naturalism purged of supernaturalism and dogmatic certainties, a topic I have explored before in some detail in my 'The Reach of the Aesthetic and Religious Naturalism' (Innis 2012).

In experience we are engaged in various modalities with only parts or sectors or regions of the field, linked to, or lured toward, them by various interests that create what James called the various 'universes of meaning' or 'multiple realities' that are extricated out of the flux of experiencing by various acts of 'abstraction.' These interest structures are embedded in, or even constituted by, what Dewey called 'problematic situations' that initiate inquiry in the most general sense of that term. In any 'situation,' a technical term in Dewey's philosophy, "the undefined pervasive quality of an experience is that which binds together all the defined elements, the objects of which we are focally aware, making them a whole" (AE 198). The recognition of the theoretical centrality of this undefined pervasive quality Dewey considered to be Peirce's most important philosophical discovery. This theme I have discussed in my essay “The 'Quality' of Philosophy: On the Aesthetic Matrix of Dewey's Pragmatism" (Innis 2011).

Eco admits that Dewey's aesthetics has naturalist, though not positivistic, foundations, even though Eco hints at that when he writes that "on the threshold of the cosmic mystery, Dewey seems to be afraid of taking the last step that would allow him to dissect this experience of the indefinite into its psychological coordinates and declares his 
failure" (OW 26). Here is the text he cites from Dewey: "I can see no psychological ground for such properties of an experience save that, somehow, the work of art operates to deepen and to raise to great clarity that sense of an enveloping undefined whole that accompanies every normal experience" (AE 199), a position derived from Dewey's appropriation of James's theme-field-margin schema of the stream of consciousness. Eco thinks Dewey gives up too quickly, that he had in fact already clarified the premises for such an explanation in earlier pages of Art as Experience, but he strangely does not cite or allude to these pages, one of which certainly contains the following passage.

We unconsciously carry over [a] belief in the bounded character of all objects of experience (a belief founded ultimately in the practical exigencies of our dealings with things) into our conception of experience itself. We suppose that experience has the same definite limits as the things with which it is concerned. But any experience, the most ordinary, has an indefinite total setting. Things, objects, are only focal points of a here and now in a whole which stretches out indefinitely. This is the qualitative "background" which is defined and made definitely conscious in particular objects and specified properties and qualities. (AE 197; original emphasis)

From the epistemological side, which is rooted in Dewey's model of experiencing, Eco characterizes Dewey's theory of knowledge as transactional. "Dewey offers us a transactional conception of knowledge that becomes particularly suggestive when set side by side with his definition of the aesthetic object. The work of art, for him, is the fruit of a process of organization whereby personal experiences, facts, values, meanings are incorporated into a particular material and become one with it." (OW 27; original emphasis). This is what Dewey called 'fundedness' and is a central key to Dewey's approach to expression, which is not a predominantly 'subjective' process. Eco cites Dewey to the effect that art is the "capacity to work a vague idea and emotion over into

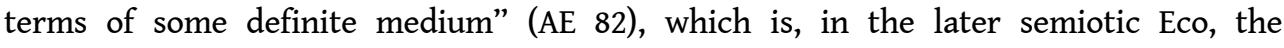
expression plane. An art work's expressive power, as Dewey put it, is dependent upon "meanings and values extracted from prior experiences and funded in such a way that they fuse with the qualities directly presented in the work of art" (AE 104).

Eco's apt citations of Dewey indicate that he is quite aware of the interlinking of Dewey's aesthetic concerns. Continuing with the theme of expression, which plays an important role in A Theory of Semiotics, Eco cites the following text which contains in nuce the core of Dewey's pragmatist aesthetics:

[...] the expressiveness of the object of art is due to the fact that it presents a thorough and complete interpenetration of the materials of undergoing and of action, the latter including a reorganization of matter brought with us from past experience [...] The expressiveness of the object is the report and celebration of the complete fusion of what we undergo and what our activity of attentive perception brings into what we receive by means of the senses. (AE 108)

As to 'matter' brought, from past experience, there is a footnote in which Eco cites Art as Experience (AE 128), which in a way takes us back to the assimilation of mixed elements notion in the Aquinas book: "[...] the scope of a work of art is measured by the number and variety of elements coming from past experiences that are organically absorbed into the perception had here and now." This means that the work of art is defined by internal relations, making up a systematic whole, but defined in perceptual terms marked by pertinence and relevance. Perception in this way becomes 'thick' in that we cannot just pass through it to something else. It is marked by form. Eco cites the following text: “[...] to have form [...] marks a way of envisaging, of feeling, and presenting experienced matter so that it most readily and effectively becomes material for the construction of 
adequate experience on the part of those less gifted than the original creator." (AE 114). In a text not cited by Eco Dewey claims that "form is a character of every experience that is an experience [...] Form may then be defined as the operation of forces that carry the experience of an agent, object, scene, and situation to its own integral fulfillment." (AE 142, Dewey's italics).

This operation of forces is something that is both done and undergone, a delicate balancing of activity and passivity that make up the poles of our encounters with the world, a process of transactions that permeate and fuse both poles. Knowledge, Eco writes, alluding beyond Art as Experience to "other texts by Dewey" (OW 27) which are not cited, is a

[...] difficult process of transaction, of negotiation: in answer to a given stimulus, the subject incorporates the memory of past experiences into the current one and, by so doing, gives form to the experience in progress - and experience that is not only the recording of a Gestalt already existing as an autonomous configuration of reality (or, for that matter, a subjective positing of the object), but that it is the result of our active participation in the world, or, better yet, the world that results from this active participation. Thus, the moment of totality (the experience of the aesthetic moment as an openness of knowledge) could very well lend itself to a psychological explanation, the absence of which makes Croce's accounts, and in part Dewey's, somewhat suspect. (OW 28)

Strangely enough, the first part of this text is almost a gloss on Dewey famous 1896 paper on the 'reflex arc' as well as on Dewey's paper on the "Does Reality Possess Practical Character?" from the James Festschrift. These papers, especially the 1896 paper, inform all of Dewey's later work, showing experience to be a widening gyre of doings and undergoings on multiple levels. Eco shows, however, an implicit, although somewhat confused, affinity with the inner logic of Dewey's work when he remarks that he (Eco) is dealing with the "very conditions of knowledge, and not just the aesthetic experience," unless he adds, aesthetic experience is "the liminal condition of all knowledge, its primary and essential phase, which is quite plausible but not exactly pertinent at this stage of our investigation" (OW 28). But, as far as I can see, Eco progressively moved toward a more explicitly 'upper threshold' framework that foregrounded cultural units, the subject of semiotics, as the access points to the various forms of transaction and their modelling, including aesthetic transactions, which Dewey very emphatically 'pushed down.' In Kant and the Platypus he admitted, with reference to Innis (1994), that this 'top down' approach, while clearly a valuable heuristic device in A Theory of Semiotics, could perhaps not do full descriptive justice to the dynamic play of forms that make up the experiential field.

In the chapter, "Analysis of Poetic Language," in The Open Work that is the focus of our attention at this moment, Eco says that his investigation "will be limited to the process of transaction between a perceiving subject and an aesthetic stimulus" and specifically to the subject's reaction to language as a paradigmatic artifact, the analysis of which can be extended, mutatis mutandis, to other art forms. Eco relies on hints from Jakobson to distinguish the characteristics of aesthetic language and to abolish the absoluteness of the distinction between the emotive and the referential use of language. Here I can only summarize Eco's account, keeping the focus on its links with pragmatism in general and Dewey in particular. The aesthetic lessons from reflecting on language as aesthetic stimulus is that the aesthetic stimulus is not purely referential. Its denotatum is global, while the stimulus itself is composed of an integration of signifying components which do 
not signify separately but belong to a field. "Form is perceived as a necessary, justified whole that cannot be broken [...] the addressee must then rely on his capacity to apprehend the complex signification which the entire expression imposes on him. The result is a multiform, plurivocal signified that leaves us at once satisfied and disappointed with this first phase of comprehension precisely because of its indefiniteness." (OW 36-7). Eco speaks of a "harmonic background" of memories, perceptual habits, and so forth that enters into "the chain reaction that characterizes every conscious organization of stimuli, commonly known as 'form"' (OW 37). Such a chain reaction is clearly not linear but more a whorl of tendencies that catch us up and that are able to "stimulate certain zones of our sensibility that previously remained untouched" (OW 38). Aesthetic value is not eternally objective and immutable or immune to transactional processes, whose matrices and surrounding conditions are not able to be specified purely in aesthetic terms. "The truth of the matter is that aesthetics is unable to give an exhaustive explanation of certain aesthetic phenomena, even when it can allow for their plausibility. The task, then, falls to psychology, sociology, anthropology, economics, and all those other sciences concerned with cultural changes." (OW 39). There is nothing in such a statement that contravenes a pragmatist approach to aesthetics, especially as developed by Dewey.

Eco summarizes his argument in the following way, which exemplifies a grasp of deep pragmatist principles:

The foregoing argument has, I hope, demonstrated that the impression of endless depth, of all-inclusive totality - in short, of openness - that we receive from every work of art is based on both the double nature of the communicative organization of the aesthetic form and the transactional nature of the process of comprehension. Neither openness nor totality is inherent in the objective stimulus, which is in itself materially determined, or in the subject, who is himself available to all sorts of openness and none; rather they lie in the cognitive relationship that binds them, and in the course of which the object, consisting of stimuli organized according to a precise aesthetic intention, generates and directs various kinds of openness. (OW 39)

That is, generates a spiral of interpretants on the affective, actional, and ideational levels. But Eco makes no reference to these dimensions in Dewey, which mirror the Peircean schema, without explicitly citing them.

\section{Aesthetic Value and Two Kinds of Openness}

Openness for Eco is the very condition of aesthetic pleasure (OW 39). This pleasure on Deweyan grounds is the felt outcome arising from a sense of completion, of having an experience that is satisfying in itself and intrinsically meaningful, apart from instrumental contexts. Clearly, Eco asserts, the multi-leveled structure of an art work shows that it cannot be "a univocal, unambiguous communication" (OW 39). Multimodal plurisignification is inherent in the aesthetic stimulus and is 'realized' in the transaction. Dewey speaks of the art product becoming the art work in the experience of the perceiver or interpreter. In this sense all aesthetic stimuli are 'open,' just as all processes of semiosis are open. If, on Peircean grounds, we really believe that consciousness is a chain of signs generating a complex trail of interpretants, all sign configurations are 'open.' They are 'realized' in accord with the forms of interpretants to which they give rise: affective, energetic, and logical, to use what is perhaps Peirce's most basic and aesthetically relevant analytical schema. There is, moreover, a 'rich' ambiguity that is 
grounded in the material embodiment of the art work and a 'weak' ambiguity that comes from mere confusion, lack of clarity or structure.

At the same time Eco admits that "semantic plurality is not enough to determine the aesthetic value of a work" (OW 41), a remark made with reference to Joyce but clearly extendible to other non-linguistic art forms. Indeed, while speaking of Finnegans Wake, although with wider implications, Eco states the ambiguity of the signs in an art work "cannot be separated from their aesthetic organization: rather, the two are mutually supportive and motivating" (OW 40). The 'total organization of the art work' in Eco's consideration is the determinant of the "density of its resonance and its provocative power" and not just its "semantic plurality" (OW 41) when we are dealing with an open work or the desire to create one. Such a plurality is dependent upon a "background of references and suggestions, thereby increasing their echoes" (OW 42). This is the fringe or margin constituting part of the Deweyan 'fundedness' that marks the forestructures of all experiential transactions and especially those with deliberately plurivocal communicational intent. Incorporation into the "right form" is necessary to engender the "fundamental openness proper to all successful artistic forms" (OW 42), including the openness resulting from our experiences of being interrupted by ordered forms that show themselves 'strange' to our antecedent systems of expectations. Eco picks up this dimension in A Theory of Semiotics. Order introduces disorder in order to introduce new forms of order. Indeed, a pragmatist aesthetics would make this process a basic principle for the development of consciousness, with no intent of discarding previous forms of order. They remain ordered contexts that present permanent possibilities of reexperiencing by being informed by the later experience of otherwise structured and ordered forms. Fundedness leads to and grounds a 'fusion.'

Disorder in communication is disorder, then, only in relation to a previous order (OW 58), where the "quotient of imagination" embodied in a 'disordering form' is its aesthetic measure and source of its novelty. When Eco speaks of the "full resonance of the poetic word" such an expression does not apply just to poetry, but to the experiential plenitude or fullness of the aesthetic form, including, it must be admitted, the elegant brevity of a Haiku or miniatures of all sorts, examples also used by Dewey. A pragmatist aesthetics, rooted in perception, clearly recognizes, along with Eco, Moles's notion of a difference threshold crossed by a novel art work, a difference registered first of all in the sense of a novel quality with dynamic tendency, a tendency toward "controlled disorder, toward a circumscribed potential [...] the germ of formativity present in any form that wants to remain open to the free choice of the addressee" (OW 65; original emphasis), grasped in a dialectics of oscillation that establishes transactional rapport.

41 Transactional rapport "constitutes the very processes of perception and reasoning" (OW 71) whose openness can be extended to "every perceptual and intellectual process" (OW 71). Such processes occur in stages and highlight aspects of their engaged field "that lend themselves to an interaction with the dispositions of the subject" (OW 71), dispositions of multiple kinds: affective, behavioral, conceptual/logical. Eco states that art deliberately provokes "incomplete experiences" so as to arouse "our natural craving for completion" (OW 74), which Dewey saw epitomized in our grasp of art and in forms of attending outside of instrumental contexts. The natural craving for completion is prolonged by the rich ambiguity and informational fullness of a work of art that counteracts psychic inertia and its promise of a recovered order instead of the pressing task of engaging a new order, which takes its place alongside other orders, challenging, modifying, enriching them. 
According to Eco we are in the case of the explicitly open work not so much concerned with a prediction of the expected as with an expectation of the unpredictable. This should be seen as a kind of aesthetic pragmatic maxim, but, in light of a pragmatist aesthetics, it is not restricted to the types of art works foregrounded and engaged by Eco.

Eco in The Open Work was clearly caught between his own philosophical transitions and perplexities and a search for analytical means to resolve them, whether in a relatively randomized appropriation of certain elements from Dewey's Art as Experience and maybe other absorbed but not cited Dewey articles or elements from the contemporary postGestalt tradition in psychology that supported the transactional psychology he thought needed to underpin an aesthetics that recognized the implications of the concept of the open work. For Eco "only a psychology concerned with the genesis of structures can justify this tendency of contemporary art" (OW 80-1), namely, of enjoying "both the equiprobability of all the systems and the openness of the process as a whole" (OW 80). Indeed, "[...] today's psychology seems to pursue its explorations in precisely the same directions taken by the poetics of the open work" (81). The open work is a concept fully consonant with a pragmatist aesthetics, which views art works and the aesthetic dimensions of experience as spiraling out of the various 'vortices of consciousness' marking Dewey's 'live creature's' involvement with the world.

Eco's psychological resources reconstitute in slightly different terms the descriptive framework informing Dewey's Art as Experience. He appropriates the conceptions of fluctuation, of perception as a commitment in which a percept is "none other than a temporary stabilization of a sensible configuration," "a fluctuating perceptual whole" which has attained a "right form" (OW 81). Dewey had stated that one of the functions of art is to show that objects must not have or be assumed to have stable properties and that art explores the lability of forms, the various forms of appearing, what Eco called "the very perishability of all patterns and all schemes" (OW 83). On Deweyan terms it is not just contemporary art that is to be seen as, as Eco puts it, "fulfilling a precise pedagogical function, a liberating role" (OW 83). Dewey ascribes this function to art itself in all its forms. The discourse of contemporary art that Eco takes as the paradigm of breaking free of the closed world of classical and modern art is not alone in its efforts "to represent modern man's path to salvation, toward the recognition of his lost autonomy at the level of both perception and intelligence" (OW 83). Art as Experience shows on practically every page that a fully developed experiential approach to art underlies all forms of art when the encrusted layers of mere perceptual and affective habits are broken through and experience is allowed to follow its dynamic toward novelty, following the upsurge of world process itself.

So Eco is right in The Open Work to emphasize, as pragmatist aesthetics does, the perceptual matrices in which the aesthetic encounter takes place. The encounter involves on both the creative and the experiential side grouping into specific forms, the unification of experiences that are unfolding in time on both the individual and social levels. He brings Dewey back into the discussion by citing one passage of Dewey: "We have an experience when the material experienced runs its course to fulfillment. Then and only then is it integrated within and demarcated in the general stream of experience from other experiences [...] In an experience, flow is from something to something." (AE 42-3; original emphasis). Dewey does not think, no more than Aquinas does, that we can live our lives in a constant state of experiential fulfillment, an unbroken sequence of 'an experiences.' Being absorbed in an art work or in an experience of nature punctuates 
everydayness in a way that a mountain range arises from a plain. 'An experience' is a contrast term as well as an evaluative term, but it is not meant to characterize all experiences such that its everyday instrumental character would be found lacking in value. But it is also the case that certain dominating structures of everydayness block the possibilities of having experiences run their course to fulfillment, precisely the criticism Dewey made of the excesses of industrial capitalism and its savaging of the environment, both urban and natural, individual and social. What Eco writes about plot applies to Dewey's point: it is "the search for, and the establishment of, a coherence, a unity, an order in the midst of chaotic diversity" (OW 111).

Eco writes that "clearly, what we find most interesting in Dewey's definition of experience is not so much the organic nature of the process (the interaction between the subject and its surroundings) as its formal aspect: the fact that he sees it as an accomplishment, a fulfillment" (OW 111; original emphasis). This is not quite right. Eco gives the impression that an experience is something that we do, that it is an achievement due to effort and can be produced by thematic control. However, one of the central themes of Dewey's aesthetics is the undergoing side, the being caught up in a process that is not something that we do. There is rather an emergent quality on the receptive side to such an experience in that it confronts us and engages us, even against our will. In fact, on Dewey's account, it is the constant interlinking of undergoing and doing that marks the dynamic spiraling circuit of behavior, a Deweyan echo in Eco's discussion. This involves constant adjustment. On the creative side Dewey is also insistent on the emergent nature of the form that arises from the various resistances that the medium puts up. The notion of resistance also marks the secondness that confronts us, marking a kind of degree of difficulty, although Dewey does not explicitly use Peircean terminology at this point in his aesthetic theory. Rather, he reconstitutes and exemplifies it, with nuance and descriptive thickness, as I have shown in "Dewey's Peircean Aesthetics" (Innis 2014).

\section{Linking Dewey to Form as Social Commitment}

Eco also engages Dewey in the chapter "Form as Social Commitment" in The Open Work where the opening theme deals with the double-faced nature of alienation. His discussion involves a serious, maybe even inexplicable, misunderstanding of Dewey's point even if the theme was also central to Dewey's aesthetic critique of modern social forms, as I have examined in a chapter on the pragmatist critique of technology in my Pragmatism and the Forms of Sense (Innis 2002). As to alienation, Eco follows the lead of the difference and polarity between the two German words, Entfremdung and Verfremdung as residing in the consequences of the universal process of objectification understood in the differently weighted senses given to that term in Hegel and Marx. Alienation 'in' the objectified world implies a self-renunciation, a becoming 'other' in a world of objects that one oneself has made and being made 'subject' to its powers. Alienation 'from' the objectified world means that one cannot see oneself in such a world, treating it as external to us, an evil, even if necessary, that we have to contend with but with the hope that ultimately we can 'wash our hands of it' by some way of destroying it. So we have alienation as self-loss or self-absorption in an objectified world and alienation as critical self-distancing from the objectified world with the hope or expectation of dominating it whether by one's own actions or some external intervention. 
It within the focus of the kind of alienation attendant upon every act of objectification that Eco introduces references to Dewey's Art as Experience into the analysis. Eco thinks there is a permanent tension involved in the Hegelian/Marxist notion of alienation 'in' an object or object world, a tension that can be eliminated "both in action and awareness, but not forever" (OW 127). As a matter of fact there is a Hegelian background to the web of concerns that informs Dewey's philosophical project and also a bearing on the dichotomy of (a) the beautiful soul and (b) "the subject's joyful dissolution in the object" (131). Embodiment in objects, the extension of corporeality into object is, Eco rightly says, the "very condition of homo faber" (132). Indeed, Dewey writes in Art as Experience (AE 286) that "the self is created in the creation of objects" and moreover "in every experience we touch the world through some particular tentacle; we carry on our intercourse with it, it comes home to us, through a specialized organ" (AE 199) with each medium having its own efficacy and value and also different effects upon the acting subject.

So, it is strange that Eco thinks that Dewey is at the opposite extreme of the beautiful soul's refusal to get its hands dirty. He wrongly ascribes to Dewey the position that the integration of man and nature can be full, so that there is exuded a putatively universal "feeling of harmony and fulfillment" (133). Here is the text he cites from Dewey:

Every experience is the result of interaction between a live creature and some aspect of the world in which he lives. A man does something: he lifts, let us say, a stone. In consequence, he undergoes, suffers something: the weight, strain, texture of the surface of the thing lifted. The properties thus undergone determine further doing. The stone is too heavy and too angular, not solid enough; or else the properties undergone show it is fit for the use for which it is intended. The process continues until a mutual adaptation of the self and the object emerges and that particular experience comes to a close [...] [The] interaction of the two constitutes the total experience that is had, and the close which completes it is the institution of a felt harmony. (AE 50)

The next paragraph gives Eco's gloss, which is woefully inadequate and misleading. Eco writes: "The tragic suspicion that a relationship with an object may fail precisely because it succeeds too much is absent from Dewey's philosophy. For Dewey, an experience can fail (that is, fail to be a full-fledged experience) only when between the person and the object there is a polarity that cannot be resolved by integration; when there is integration there is experience, and an experience can only be positive." (OW 134). But in fact Dewey's position is quite otherwise.

Dewey's text is normative, not descriptive. Felt harmony with self and other is the goal of human experience in its individual and social forms, but Dewey's aesthetics with its distinction between normal experience and an experience presupposes that the ineluctable resistances that mark our lives in a world filled with peril and perpetual perishing can never be permanently overcome. The ideal is not total integration - a utopian phantasy - but the institution of frameworks and matrices of perception and action that correspond to the constraints of our lives in time. Dewey is neither unrealistically optimistic nor depressingly pessimistic but rather, in line with pragmatist principles, melioristic. He is not fearful that embodiment leads inevitably to alienation.

51 Here are two texts where the double tendency in Dewey's 'aesthetic critique' of the technological world is exemplified. The first text has a positive tone.

Where the worker produces in different industrial conditions from those which prevail today, his own impulsions tend in the direction of creation of articles of use that satisfy his urge for experience as he works. It seems to me absurd to suppose 
that preference for mechanically effective execution by means of a completely smoothly running mental automatisms, and at the expense of quickened consciousness of what he is about, is ingrained in psychological structure. And if our environment, as far as it is constituted by objects of use, consisted of things that are themselves contributory to a heightened consciousness of sight and touch, I do not think any one would suppose that the act of use is such as to be anesthetic. (AE 266-7) to move more easily in this world" (OW 150). Both argue that the continuous flux of existence and the 'sea of objectivity' (Calvino) cannot be met with passive adherence or be opposed by relying on an uncritical "ideal human standard of measurement" (OW 150). The new human standard of measurement, which Eco saw needed, is precisely the model grounded in the tracing, with an aesthetically normative eye, of the development of forms of experiencing which Dewey aimed at, exploiting James's insights and also Peirce's theory of quality. Speaking of the flux of existence with its emergent islands of order of various sorts is, as both Eco and Dewey would agree, already to begin to judge it. In judgment we alienate ourselves from it and as a result "take the first step toward repossessing it" (OW 151). expressing "our relationship to the object of our knowledge, and our concern with the form we have given the world, or the form we have failed to give it" (OW 157). Eco says about the artistic process quite generally that it "tries to give form to disorder, amorphousness, and dissociation." It is "the effort of a reason that wants to lend a discursive clarity to things" (OW 157), which aesthetics, as an analytical discipline operating in the mode of theory and not exemplification, also achieves. Dewey, a persistent searcher for discursive clarity, writes in the chapter on 'Art and Civilization' in Art as Experience in a passage that could have been written by Eco:

Words furnish a record of what has happened and give direction by request and command to particular future actions. Literature conveys the meaning of the past 
that is significant in present experience and is prophetic of the larger movements of the future. Only imaginative vision elicits the possibilities that are interwoven within the texture of the actual. (AE 348) There are references to a transactional account of perception in Kant and the Platypus which I mentioned earlier. There is one at least third hand reference, through Putnam, to James's contention that "knowledge of facts presupposes knowledge of theories, knowledge of theories presupposes knowledge of facts." The references to Peirce make up almost a half column in the index of Kant and the Platypus and are strewn throughout the text but clearly involved in Eco's return to the problem of iconism. But Kant and the Platypus has minimal aesthetic relevance and even less to determining Eco's relation to pragmatism. He is speaking to a quite different audience and with quite different resources. Still, in concluding this examination of key aspects of Eco's relation to pragmatism, it is necessary to look, albeit briefly, at the section on 'Aesthetic Text as Invention' in A Theory of Semiotics to see whether in this pivotal work of Eco taking up the lost trail of Dewey could have enriched and maybe even reconfigured this 'breviarium aestheticum' that nevertheless still remains of heuristic value for understanding both Eco's aesthetic framework, clearly semiotic, and its relation to Dewey's pragmatist approach.

\section{Pragmatist Dimensions of the Aesthetic Text as Invention}

Eco clearly formulates the general matrix of his approach to aesthetics in A Theory of Semiotics by exploiting the notion of 'text,' a distinctively semiotic theme. There are nevertheless illuminating points of intersection between his schema and Dewey's model of aesthetic experience. Eco's hope is that such a semiotic approach to 'aesthetic texts' may help to throw light on "many problems that traditional philosophical aesthetics has left unsolved" (TS 261). He does not specify what he means by the blanket term 
'traditional,' which Dewey's experience-grounded and explicitly pragmatist aesthetics definitely is not.

Eco returns in A Theory of Semiotics to Jakobson's well-known foregrounding of the ambiguous and self-focusing nature of the sign-configurations of poetic language. Eco follows, as we have seen, Jakobson's claim that ambiguity arises from violating the rules of the code, including forms of stylistic ambiguity, in that an expression can be 'grammatical' yet not 'normal.' Ambiguity, on Eco's account, can "function as a sort of introduction to the aesthetic experience" (TS 263). It does not produce more disorder or confusion but urges or stimulates an interpretive effort (actually, it involves 'difficulty') in that it 'resists' us, clearly a hermeneutic manifestation of Peircean secondness. While Dewey, as he remarks in his 1946 essay, 'Peirce's Theory of Linguistic Signs, Thought, and Meaning,' does not find the Peircean theory of categories a 'happy' one, he does recognize felt resistance as a multi-leveled factor in the art work that interrupts us and blocks our passing through it to something else. Resistance on the aesthetic plane involves the material 'thickening' of the sign-configuration or the breaking of an interpretive habit, which may not be able to be systematically controlled or even formulated.

Ambiguity on the expression plane entails ambiguity on the content plane. Eco follows the Russian formalists in arguing that there is beyond the felt sense of resistance a shock, a feeling of a break, such that the receiver of the aesthetic message is forced to reconsider "the entire organization of the content" (TS 263). Dewey's pragmatist aesthetics recognizes this aesthetic as well as existential phenomenon: that art works 'make strange' and, in instances of the sublime, elicit a sense of bewilderment by increasing "the difficulty and the duration of perception" (TS 264, citing Viktor Shklovsky 1917), an apt characterization of one of Dewey's fundamental principles. Just as a deep quarrel with an old friend can force us to reconsider a lifetime of closeness, the encounter with art works can do the same. Dewey saw art as wiping away the film that covers objects and episodes and making us see them as if for the first time, creating a particular perception through the art work as revealing that the perception of objects is always an 'open' process that both stabilizes forms of perception through the material configuration of the art work and destabilizes them by revealing new properties and aspects. But it is to the formalists that Eco turns here and not to Dewey and the pragmatists. The Deweyan phenomenology of experience, with its roots in James and Peirce, offers us important ways of understanding the phenomenon that the formalists developed from a rather different angle.

63 Without mentioning Dewey Eco foregrounds the centrality of rhythm and of rhythmic violations, a topic central to Dewey's analysis of aesthetic experience. Eco once again follows Victor Shklovsky: "aesthetic rhythm consists of a prosaic rhythm that has been violated [...] it is a question not of complex rhythm but of violation of that rhythm and of a violation such that it cannot be predicted; if violation becomes the rule, it loses the force that it had as an operational obstacle." (Shklovsky 1917; cited TS 264). It is precisely the violation of the expected, a break in background rhythm that makes the art work (text) become self-focusing, with a rhythm of its own, and thereby "directs the attention of the addressee primarily to its own shape" (TS 264; original emphasis), that is, its form.

As to the role of rhythm, Dewey writes, "Esthetic rhythm is a matter of perception and therefore includes whatever is contributed by the self in the active process of perceiving" (AE 167-8), that is, it is a funded process, rooted in the body. It is an "ordered variation of energy" and "variation is not only as important as order, but it is an indispensable 
coefficient of esthetic order" (AE 169). Rhythm is "rationality among qualities" (AE 174), a form of aesthetic rationality. Indeed, "art operates by selecting those potencies in things by which an experience - any experience - has significance and value [...] Order, rhythm and balance, simply means that energies significant for experience are acting at their best." (AE 189). Rhythmic crises quite generally punctuate "the stream of living" (AE 12), destabilizing and unbalancing. Art and aesthetic experience further processes of stabilizing and balancing while also introducing movement away from the encrustations of habit. Rather than reifying art, Dewey holds that "art is a quality that permeates an experience; it is not, save by a figure of speech, the experience itself. Esthetic experience is always more than aesthetic. In it a body of matters and meanings, not in themselves aesthetic, become esthetic as they enter into an ordered rhythmic movement toward consummation." (AE 329; original emphasis). At no point in his discussion of aesthetics in A Theory of Semiotics does Eco allude to Dewey's ideas about rhythm, although Dewey is listed in the bibliography of Trattato generale di semiotic but not in A Theory of Semiotics. At the same time Eco says nothing that contravenes the thrust of Dewey's work and his brief foregrounding of it is a motivation to investigate what a semiotic aesthetics, with its emphasis on sign-configurations, can contribute to the study of rhythm. Dewey's absence at this point in Eco's discussion provokes reflection on his claim about the important influence of his reading of Art as Experience.

As to the fundamental role the "lower levels of the expression plane" play in art and aesthetic experience (TS 264; original emphasis), they deserve, Eco says, a semiotic explanation, themes taken up in Kant and the Platypus but with minimal aesthetic discussion. Here Eco opens up the important issues of prethematic microstructures, inner textures of materials, qualitative feels, and senses of pertinence and salience that inform and constitute a "whole series of hypostructures" (original emphasis) which clearly exist on the perceptual stratum. James and Dewey would have been of great help here, as would others working out of different traditions, such as Polanyi's account of tacit knowing and subsidiary awareness, which I have discussed elsewhere. Eco speaks of how we are to conceive the "unshaped continuum" as being structured into a set of cultural units segmented by a kind of syntactic system that gives rise to a "structured set of signal-units" (TS 266). As he conceives it, "the stuff of which the sign-vehicle is made is the continuum from which the expression form has cut out its expression units" (TS 266). Dewey's great rich and dense chapters on the 'substances' of the arts bears directly on this whole domain, which Eco formulates primarily with the help of Hjelmslev's schemas.

However, such a way of putting it seems to imply that this involves an action on the expression form rather than the expression form itself emerging out of the artist's striving to find an appropriate support of what one wants to express. The continuum itself has expressive possibilities that 'fit' the content, having a kind of 'rightness' or 'affinity.' This appears to be the point of Dewey's masterful reflections on the mediums or 'substances' of the various arts, their material underpinnings. But, even on the semiotic level, is there not some danger of speaking of "expression units" as if they could make up some sort of 'vocabulary'? At the same time Eco is certainly right when he claims that "in the aesthetic text the matter of the sign-vehicle becomes an aspect of the expression-form" (TS 266; original emphasis), informed by what Peirce called its material quality. A task for a pragmatist semiotic approach to the aesthetic is to explore how far down the field of hypoforms goes within the domain of 'significations,' especially 'affective' significations. Eco also does not advert to the notions of an aura, fringe, and so forth that Dewey, following James, 
explored, notions that permeate Art as Experience. He gestures toward microstructures, but his basis is far from the analytical tools derived from pragmatism. Although he is right to admit 'lower levels' of signification and communication, he has constant recourse to linguistic examples. Should he not be talking about a pre-thematic field of habits of attending that shift according to apprehended centers and arrays of pertinence and salience that he discussed in all too brief fashion in Kant and the Platypus?

As to the question of what type of relation exists between "the further segmentation of the token matter of a given sign-vehicle and the further segmentation of the expression plane of an entire semiotic system" (TS 268; original emphasis), Eco rightly considers this a process of pertinentization "of those aspects of the expression-continuum that have up to now been considered as "hyposemiotic stuff" (TS 268). A pragmatist aesthetics would certainly agree that "a work of art performs a semiotic redemption of its basic matter" (TS 268) and does so by a process of infinite pertinentization, a process recognized by Dewey and James and indeed is implicit in Peirce's theses on indeterminacy, including perceptual indeterminacy. Eco strangely claims that "as long as semiotics continues to develop, the continuum will be further segmented and therefore better understood: the aesthetic experience provides a special opportunity for increasing this understanding" (TS 269; original emphasis). Surely it is semiosis, including aesthetically pivotal perceptually focused semiosis, that continues to develop, with semiotics being the reflection upon its processes. Analysis of processes of semiosis such as aesthetic semiosis are second order processes. The task is to find the appropriate set of broadly pragmatist analytical categories that are able to encompass the tension between perception and semiosis in the aesthetic dimension of life. It may be asked whether Eco ever satisfactorily gave an account of this matter. I have discussed elsewhere ways of doing this (see references).

For Eco the well-known surplus of expression is paralleled on the part of the addressee by a vaguely sensed surplus of content, a surplus still aroused even when the surplus of expression is not "consciously grasped" (TS 270). Eco admits that one might be tempted to think that a work of art communicates too much and as consequence does not communicate at all, casting as a result a magic spell "that is radically impermeable to all semiotic approach" (TS 270). Eco retorts:

[...] a work of art has the same structural characteristics as does a langue. So that it cannot be a mere 'presence'; there must be an underlying system of mutual correlations, and thus a semiotic design which cunningly gives the impression of non-semiosis. (TS 271; original emphasis)

Eco writes that the art work as structure of mutual correlations has achieved "a new status as a super sign-function" (TS 271; original emphasis). I think that Dewey's perception-based organic notion of an art work with mutual levels and systems of interacting energies also recognizes many underlying systems of mutual correlations, but the reference to langue shows Eco's commitment to an underlying semiotic model based on language and the notion of a text. Such a model, while suggestive, is not sufficient and even Eco refers to "structural characteristics" rather than affirming that art works belong to language-like systems. Art works can be, and certainly, are sign-configurations, but they do not rely on coded systems of differential markers in the way language-like systems do. Dewey's aesthetic model is complemented richly by such a model as Susanne Langer developed, which bound together feeling, perception, and signification in a powerful account of the genesis and nature of an art work. 
Peirce and Dewey show that it is the qualitative uniqueness of every work of art that gives rise to and support its array of appropriate interpretants. This is in fact a process of abduction, accompanied by a kind of hypothetical tension, felt as a distinctive quality, aroused, for example, by a piece of music, but also possessed by all art works in different degrees. Eco writes that there occurs in the aesthetic encounter a 'release' of a "strong and complex feeling" (TS 274) but also a sense of being engaged, even opposed, by an 'other' that is communicating some 'sense' to us. So, Eco is right to say that art produces further knowledge and does not merely elicit an arbitrary set of individual feelings. Affective interpretation means recognizing not just how one is affected but whether one's feeling-response is appropriate to the form (perhaps an echo of the remarks about music in Eco's discussion of music in Aquinas). In the aesthetic encounter we are pulled into a game of intertwined interpretations and accompanying experiences, as I have discussed elsewhere (Innis 2007). We are pulled 'inside' the art work to dwell in it, being caught up in it through progressive processes of apprehending and differentiating the material qualities and the resultant 'tone' of the work. An art work makes us aware of new semiosic possibilities and trains not just semiosis at the upper levels but the lower thresholds of experience itself out which art emerges as the transfiguration of matter into sense.

71 Eco writes: "Like a large labyrinthine garden, a work of art permits one to take many different routes, whose number is increased by the criss-cross of its paths." (TS 275). Eco is right to follow Peirce in arguing that all forms of inference are in play in the 'reading' or 'perceiving' of an artwork and that aesthetic abduction, in one sense, "consists in proposing certain tentative codes in order to make the author's message understandable" (TS 275). But a pragmatist aesthetics, such as developed by Dewey against the background of James and Peirce, with its focus on constructive experiential participation in the play of elements both broadens and diminishes the notion of code to one of differentiated systems of interpretive habits on the affective, actional, and ideational levels both personally and socially. These make up the schema of 'forestructures' or dimensions of the aesthetic encounter and correspond to the schema of Peircean interpretants. They are 'filled' or 'generated' in the actual encounter, where there is always a permanent tension between fidelity and freedom (TS 276), a tension exemplified in the 'open work' but constitutive of all art works that reveal new thresholds of sense.

We walk in the labyrinthine garden of art, and we follow a variety of paths which are predefined even if we choose, under restraints, the actual itinerary. Dewey's aesthetics bears in multiple ways upon Eco's theme of the open or indeterminate nature of an art work. His pragmatist aesthetics shows art works to be grounded in meaning-structures that at all levels are perceived and not separable from their sense, no matter what their signifying support structure should be. As Dewey writes: “[...] there are other meanings that present themselves directly as possessions of objects which are experienced. Here there is no need for a code or convention of interpretation; the meaning is as inherent in immediate experience as is that of a flower garden." (AE 89).

Such a contention by Dewey, looked at in light of the preceding tracing of the lost trail of Dewey in Eco's work, is not so much a refutation of Eco's aesthetic model and its perceptual and social underpinning, as a pointer to what further paths in determining the pragmatist dimensions of Eco's work, beyond the Peircean, could profitably be pursued. 


\section{BIBLIOGRAPHY}

DEWEY John, (1896/1998), “The Reflex Arc Concept in Psychology,” in Larry A. Hickman \&

Thomas M. Alexander (eds), The Essential Dewey, vol. 2, Bloomington, Indiana University Press.

DEWEY John, (1922/1983), Human Nature and Conduct, Critical Edition, Carbondale, Southern Illinois University Press.

DEWEY John, (1925), Experience and Nature, Critical Edition, Carbondale, Southern Illinois University Press.

DEWEY John, (1931), “Affective Thought,” in Id., Philosophy and Civilization, New York, Henry Holt.

DEWEY John, (1931), Philosophy and Civilization, New York, Henry Holt.

DEWEY John, (1934/2008), Art as Experience, Carbondale, Southern Illinois University Press (cited as $\mathrm{AE})$.

DEWEY John, (1935/1998), “Peirce's Theory of Quality,” in Larry A. Hickman \& Thomas M.

Alexander (eds), The Essential Dewey, vol. 2, Bloomington, Indiana University Press.

DEWEY John, (1946), “Peirce's Theory of Linguistic Signs, Thought, and Meaning," Journal of

Philosophy, 43.4, 85-95.

ECO Umberto, (1978), A Theory of Semiotics, Bloomington, Indiana University Press (cited as TS).

ECO Umberto, (1988), The Aesthetics of Thomas Aquinas, trans. by Hugh Bredin, Cambridge, Harvard University Press (cited as ATA).

ECo Umberto, (1989), The Open Work, trans. by Anna Cancogni, introduction by David Robey, Cambridge, Harvard University Press (cited as OW).

ECO Umberto, (1991), The Limits of Interpretation, Bloomington, Indiana University Press.

ECO Umberto, (1999), Kant and the Platypus: Essays on Language and Cognition, trans. by Alastair McEwen, New York, Harcourt (cited as KP).

ECO Umberto, (2014), From the Tree to the Labyrinth: Historical Studies on the Sign and Interpretation, trans. by Anthony Oldcorn, Cambridge, Harvard University Press.

HICKMAN Larry A. \& Thomas M. ALEXANDER (eds), (1998), The Essential Dewey, vol. 2, Bloomington, Indiana University Press (cited as ED).

INNIS Robert E., (1994), Consciousness and the Play of Signs, Bloomington, Indiana University Press.

INNIS Robert E., (2002), Pragmatism and the Forms of Sense: Language, Perception, Technics, University Park, The Pennsylvania State University Press.

INNIS Robert E., (2007), “Dimensions of an Aesthetic Encounter," in SunHee Kim Gertz, Jaan Valsiner \& Jean-Paul Breaux (eds), Semiotic Rotations: Modes of Meaning in Cultural Worlds, Charlotte, Information Age Publishing, 113-34.

INNIS Robert E., (2009), Susanne Langer in Focus: The Symbolic Mind, Bloomington, Indiana University Press. 
INNIS Robert E., (2011), “The 'Quality’ of Philosophy: On the Aesthetic Matrix of Dewey's Pragmatism," in Larry A. Hickman, Matthew Caleb Flamm, Krzysztof Skowronski \& Jennifer A. Rea (eds), The Continuing Relevance of John Dewey: Reflections on Aesthetics, Morality, Science, and Society, Amsterdam, Rodopi, 43-60.

INNIS Robert E., (2012), "The Reach of the Aesthetic and Religious Naturalism: Peircean and Polanyi Reflections," Tradition and Discovery, 38/3, 31-50.

INNIS Robert E., (2013), “Peirce's Categories and Langer's Aesthetics: On Dividing the Semiotic Continuum," Cognitio, 14.1, 35-50. Reprinted in Journal Phänomenologie, 45/2016, 20-34.

INNIS Robert E., (2014), “Dewey’s Peircean Aesthetics," Cuadernos de Sistemática Peirceana, Bogatá, Centro de Sistemática Peirceana, 139-60.

INNIS Robert E., (2016), "Energies of Objects: Between Dewey and Langer," in Das Entgegenkommende Denken, Berlin, Springer Verlag, 21-38.

INNIS Robert E., (2018), "Peirce and Dewey Speak about Art: Quality and the Theory of Signs," To appear in Semiotica, special issue on the relevance of Peirce's later theory of signs.

PAREYSON Luigi, (1954), Estetica. Teoria della formatività, Turin, Edizioni di Filosofia.

SHKLOVSKY Viktor, (1917), “Art as Device," now in Theory of Prose, trans. by Benjamin Sher, Normal, Illinois, Dalkey Archive Press, 1990.

\section{ABSTRACTS}

Umberto Eco's philosophical project, which culminates in the development of a systematic and philosophically relevant semiotics, has a perplexing and problematic debt to and link with pragmatism in its many forms. Indeed, his apparent relation to pragmatism as such is in fact quite tangential if we ignore the pivotal role of Peirce in defining and supporting Eco's explicit semiotic turn. But Eco claimed that John Dewey's Art as Experience, the foundation of a distinctively pragmatist aesthetics, was a major factor in his early philosophical movement away from certain premises of the aesthetic tradition that held sway during his student days. Eco engages Dewey in surprising and enlightening ways in his early books, but the trail of Dewey is gradually 'lost.' It is this trail, wandering through different contexts, that I follow in this paper. I also indicate how Dewey's work could have played a larger role in Eco's mature aesthetic thought and that we should see the absence of Dewey to represent a lost opportunity for emphasizing and enriching the pragmatist side of a semiotic approach to aesthetics.

\section{AUTHOR}

\section{ROBERT E. INNIS}

University of Massachusetts Lowell and Aalborg University Denmark rinnis41[at]gmail.com 